УДК94(47).083

DOI 10.18413/2075-4458-2019-46-1-138-153

ФИНАНСОВОЕ ПО.ЛОЖЕНИЕ РОССИИ. 1914-1917 Г. (ЗАМЕТКИ НА ПОЛЯХ ИСТОРИЧЕСКИХ ТРУДОВ). ЧАСТЬ 2

\title{
FINANCIAL STATUS OF RUSSIA.1914-1917. (NOTES ON THE MARGINS OF HISTORICAL WORKS). PART 2
}

\section{И.М. Пушкарёва \\ I.M. Pushkareva}

\author{
Институт российской истории Российской академии наук, \\ Россия, 117036, г. Москва, ул. Дм. Ульянова, д. 19 \\ Institute of Russian History, Russian Academy of Sciences \\ 19, Dm. Ulyanov st., Moscow, 117036, Russia \\ E-mail: pushkarev@mail.ru
}

\begin{abstract}
Аннотация
В статье анализируются исследования, посвященные финансам как стержню экономической истории России периода Первой мировой войны. Отталкиваясь от материалов проведенного историографического анализа, автор включается в дискуссию о неизбежности или случайности революционного взрыва. Основная идея заключается в том, чтобы подтвердить первичность изучения финансов и финансовой политики императорских и временных правительств в России, принять участие в дискуссиях о проблеме неизбежности (или случайности) революционного взрыва в начале февраля 1917 года. В отношении к финансовому положению России в войне в отечественных трудах господствует «позитивная» точка зрения. Она исходит из общего состояния страны к началу войны, которое и современниками оценивалось как «вполне стабильное», но она затемняет то, что происходило в годы войны, перекладывая ответственность за развал страны на революционный взрыв и на социальную политику. История российских финансов во время Первой мировой войны рассматривается как актуальная для современного мира, позволяя увидеть в прошлом проблемы сегодняшнего дня
\end{abstract}

\begin{abstract}
The author studies historical researches dedicated to the finances as a central point of Russian economic history of the First World War period. The historiographical analysis lets the author join the discussion on the certitude or accidentality of the revolutionary storm. The main idea is to confirm the primacy of studying the finances and financial policies of imperial and provisional governments in Russia, to take part in the discussions about the problem of the inevitability (or randomness) of a revolutionary explosion in early February 1917. In the domestic historiography prevails (positive» point of view concerning the financial position of Russia in the war. It proceeds from the general state of the country at the beginning of the war, which was assessed as «quite stable» by contemporaries; it darkens what was happening, shifting responsibility for the collapse of the country to a revolutionary explosion and social policy. The history of Russian finances during the First World War allows us to find out the roots of modern problems in the past.
\end{abstract}

Ключевые слова: историография; Первая мировая война; Министерство финансов России; финансы; Барк Л.П.; налогообложение; подоходный налог; Россия.

Keywords: historiography; First World War; Ministry of Finance of Russia; finances; Bark L.P.; tax assessment; income tax; Russia.

Правительство вынуждено было выдавать каждый месяц крупные субсидии, ссуды и авансы монополиям и отдельным капиталистам, занятым военным производством. Каждый месяц из общей суммы расходов казны черпались миллионы на войну; в итоге за 
1914-1916 гг. из 19,8 млрд рублей на военные нужды было израсходовано уже - 61,6\% (12, 2 млрд).

Продолжение войны сильно настораживало Министерство финансов. Она затронула фондовый рынок, эмиссию, обращение всех видов ценных бумаг (государственных, общественных и частных) на организованных биржевом и внебиржевом рынках, когда спрос и предложение определяли их стоимость. Как рукой сняло недавнее благополучие в этой сфере.

Население не только в России, но и во всех странах охватила паника уже за неделю до объявления войны. С 12 июля 1914 г. везде во всех зарубежных европейских городах (Вена, Берлин, Будапешт, Брюссель, Париж) трясло биржи, организации предпринимателей. В России (Петербург, Москва) расстройство кредита и денежного обращения началось с внезапно подорожавшей иностранной валюты. Нависла угроза сокращения и прекращения важных закупок Россией за границей сельскохозяйственной техники и т. д. 15 июля 1914 г. в России закрылись биржевые собрания. 19 июля в день объявленной мобилизации была приостановлена работа Петербургской биржи. Задача восстановления ее работы стала одной из первоочередных и Министерства финансов.

Здесь также нужно отдать должное усилиям П.Л. Барка, слаженному организованному им аппарату министерства, а также его связям и авторитету за рубежом. Ситуация с финансами в России стала меняться относительно быстро. В 1915 г. она уже улучшилась на биржах, предприятия получали заметную прибыль, могли давать неплохие дивиденды; на денежном рынке появился избыток свободных средств, а 1916 г. вообще он стал довольно значительным [Лизунов, 2014б, с. 478]. Труднее было разобраться с проблемами, затрагивавшими миллионы людей.

Тяготы войны все сильнее проступали при обращении к источникам пополнения финансов через бумажноденежную эмиссию, налоги и займы. Золотой запас таял как весенний снег по разным статьям. Из подвалов Государственного банка российское золото перекочевывало в Англию и США в качестве платы за кредиты на производство вооружения. Еще осенью 1914 г. в Англию было отправлено золото на сумму 8 млн ф. ст. (80 млн руб.) [Соколов, 2014, с. 499-501]. С этого времени и примерно до февраля 1917 г. царское правительство в адрес союзнических поставок выслало за рубеж «желтого металла» на сумму более 640 млн руб. (т. е. чуть менее половины предвоенного золотого запаса). Внешний и внутренний государственный долг России к началу 1917 г. с 1914 г. вырос с 8,8 до 39,4 млрд руб., т. е. в 4,5 раза [Петров, 2014в, с. 382-383].

Россия была в числе первых государств, которые перевели денежное хозяйство на исключительное использование неразменных бумажных денежных знаков. Замечу, сегодня многие историки считают, что первопричиной ухудшении положения населения является денежная эмиссия, инициирующая в числе прочих факторов рост недовольства в обществе, протестного движения в России [Петров, 19146, с. 474-475]. Советская историография склонялась к тому, что главным были налоги.

До войны население России активно пользовалось услугами банковского сектора. На 1 января 1914 г. растущую сеть банков венчали учреждения Государственного банка с удельным весом в 38 \% от общего объема кредитных операций. В эту финансовую систему входили Крестьянский поземельный, Дворянский земельный, 50 коммерческих банков, 319 городских, 1108 обществ взаимного кредита. Денежные вклады населения накануне войны превышали 2,5 млрд руб., вырастали и объемы кредитования. Война обрушила все денежное обращение в стране.

Колоссальные военные затраты покрывались в первую очередь эмиссией бумажных знаков с того момента, когда размен государством бумажных денег на золото был прекрашен согласно решению Совета министров от 23 июля 1914 г. Золото и серебро быстро повсюду исчезали из обращения в такой последовательности: золотые монеты, серебряные, а потом и медные деньги [Соколов, 2014, с. 499].

С 1913 г. общая сумма бумажных денег, находившихся у людей в обращении, возросла с 1,5 млрд до 10 млрд к 1917 г. Шло безудержное падение курса и бумажного рубля. 
Тревога по этому поводу нарастала в стране не только среди низкооплачиваемых категорий наемного труда, но и в средних слоях населения, у служащих и рабочих с достаточным заработком, во всем обществе. Уже к 1915 г. рубль стоил 80 довоенных копеек, в 1916 г. - 55 копеек, на 1 марта 1917 г. - 27 копеек [Дьячков, Челноков, 1974, с. 138] и это при росте дороговизны, нехватки товаров. К тому же в промышленных центрах время от времени обнаруживался дефицит денежной наличности. В тексте шифрованной телеграммы 1916 года министру внутренних дел из Риги упоминалось, что приостановка заводов и фабрик вследствие неполучения банкам денег и невыдачи вкладов рабочим «грозит серьезными осложнениями».

Доверие к правительству падало, усиливая антивоенные настроения. В финансовом ведомстве одновременно с ведомством МВД готовились к противостоянию «неблагоприятным» настроениям населения. В денежном обороте к 1917 г. стали появляться непонятные разменные «успокаивающие» казначейские знаки. Они использовались вместо печатания денег по 12 видам косвенных налогов и одновременно с введением новых [Соколов, 2014 , с. 500], но растущее финансовое неблагополучие трудно было скрыть.

С начала войны правительство напечатало кредитных билетов на 7,5 млрд руб. [Петров, 2014a, с. 704] Количество бумажных денег, пущенных в обращение к началу 1917 г., выросло до 9 млрд 103 млн руб., т. е. их появилось в 5,6 раза больше, чем было в канун войны [Петров, 2014в, с. 380].

Затраты на войну к этому времени достигли 30,5 млрд руб. (это составило примерно 9 расходных бюджегов 1913 г). Каждый день обходился казне в 3 млн руб. Эмиссия бумажных денежных знаков к моменту Февральской революции покрывала треть (34\%) военных расходов [Захаров, Петров, Шацилло, 2006, с. 263].

Начался поворот на проторенную дорогу - обращение к налогам и займам. Известно, что с середины XIX в. в имперской России положительные результаты прямого и косвенного преобразований налогообложения становились важнейшим условием динамичного экономического развития страны. В официальных документах так, не скрывая, и говорилось: «Связанные с войной огромные расходы государственного казначейства, а также вызванные обстоятельствам военного времени сопротивления большей части доходных поступлений», повлекли за собой «незамедлительность подкрепления средств казны путем повышения существующих и установлением новых налогов» [Цит. по: Кравцова, 2003 , c. 502-503].

Известный интерес представляет налоговое обложение до войны для сравнения с военным временем. Замечу, что существует мнение, будто до войны в России «налоговое бремя распределялось более-менее справедливо». Б.Н. Миронов подчеркивает, что в начале XX в. к прямым налогам были привлечены «не как было ранее» исключительно русские крестьяне, мещане и купцы, а теперь и другие социальные слои, группы населения: дворянство, чиновники, казаки, национальные меньшинства. Многие налоги ложились на горожан, хотя рабочие налогов не платили (внимание, исследователи: советская историография опускала этот факт) [Миронов, 2010, с. 93-94]. Центральная Россия несла наибольшее бремя налогов по сравнению с окраинами, «создавая угнетенное положение в среде дворянского землевладения», а «окраины высасывали богатства из центра». «Страна превращалась в воронку: благосостояние отдельных ее частей было тем ниже, чем дальше они от периферии, чем ближе они были к центру», писали современники.

Замечу, считается, что на долю крестьянства, составлявшего $80 \%$ населения, приходилось $32 \%$ всех налогов и платежей [Труды местных комитетов... Симбирская губерния, 1903, с. 521; Труды местных комитетов... Тверская губерния, 1903, с. 35; Труды местных комитетов... Воронежская губерниях, 1903, с. 459; Миронов, 2012, с. 484]. Но с налогами на крестьянское хозяйство до войны не все ясно. Т.М. Китанина приводит цифры экономиста 20-х гг. Н.Д. Кондратьева, который писал о 17,6 \% «условно чистого дохода с крестьянских хозяйств». А.М. Анфимов дает другие цифры: прямые налоги с дохода крестьянских хозяйств в начале $\mathrm{XX}$ в. составляли $6 \%$. С ним сегодня соглашаются наши ис- 
торики и зарубежные исследования. До войны налогообложение с реализации единицы с/х продукции в 3-4 раза превышало налогообложение дохода с реализации промышленной продукции [Китанина, 2016, с. 22-23]. Брать дополнительные финансы с деревни было привычно и в войну.

В 1914 г. начало военных действий совпало с разгаром полевых работ в России. Значительная часть взрослого мужского населения была мобилизована, произошел неизбежный массовый отлив в армию главных производителей - мелких хозяев, ежегодно выбрасывавших в общую финансовую казну продуктов на миллиарды рублей. Способность русского крестьянства к приспособлению и выживанию стала решающей в обращении финансового сектора правительства к жизнедеятельной этой «низовой структуры» в получении с нее дополнительных доходов. При всех трудностях урожай осени 1914 г. был спасен; по данным Министерства финансов по 63 губерниям он составил 4191,9 млн пудов, но всего 16,7\% по сравнению с 1913 г. [Китанина, 2016, с. 80-82] Однако крестьянское население стало сдержанно предлагать свой хлеб на продажу. Правительство же в свою очередь стремилось втянуть его в новые условия существования и получить именно с него доходы как компенсацию в связи с потерями казной в результате прекращения свободной продажи спиртных напитков, выдачи по довоенным законам казенных денежных пособий семьям солдат мобилизованным на войну.

В 1914-1916 гг. фундаментальные издания Министерства финансов («Вестник финансов», «Торгово-промышленная газета», газета «Народное хозяйство») отражают на основании отчетов его отделений в губерниях и других банков усилия правительства в подведение итогов финансовых потерь Государственным банком. Целью последнего было внесение нужных корректив в будущую работу Министерства финансов.

Для финансирования войны нужен был снова сильный нажим на крестьянство, на которое уже с начала войны был возложен военно-грузовой и др. налоги. Нельзя было не учитывать последствия разрушения аграрного рынка, резкий спад аграрной экономики во многих регионах [Тагирова, 2014]. Предугадывая, в частности, последствия плохого обеспечения населения продовольствием, циркуляр министра внутренних дел был острожен с нажимом на деревню. Стремясь остановить инфляцию, власти накладывали административные ограничения на рост аграрных цен. Но росли быстро цены на промышленные изделия, что отражалось не только на простых покупателях города и деревни. Скрытая инфляция сопровождалась незаинтересованностью производителей в выпуске и реализации продукции при быстром нарастании дефицитов, а также протестами в попытках властей ответить на экономический вызов административными методами. Несогласованность в установлении цен приводили к спекуляции, у крестьян подрывалась заинтересованность в реализации продуктов и прежде всего - хлеба: получалось, что на вырученные ими деньги мало что можно было купить. Цены на недеревенские продукты и на промышленные изделия росли, а поставки их в деревню сокращались [Соколов, 2014]. «Путали все карты» у финансистов и меры по ведению «сухого закона».

П.Л. Барк корректировал по-своему отказ от политики прежнего министра финансов В.Н. Коковцова (апрель 1906 - январь 1914), опиравшегося на доходы от казенной винной монополии. К началу мировой войны доминирующее значение в винной государственной монополии стали приобретать фискальные интересы, а задача уменьшения народного пьянства в министерстве финансов отходила на второй план, доходы казны к войне достигли по этой статье с 1904 г. до 500 млн в год. Финансирование попечительства о народной трезвости сократилось в два раза, идея предотвращения массовой алкоголизации канула в Лету. Возникла другая: увеличение подоходного налога за счет отказа от винной монополии.

Замечу, что советскими историками и та, и другая темы отражались в кривом зеркале современности. Они всплыли на международном коллоквиуме в 1998 г. в докладе американского историка Артура Мак-Ки на основе впервые им вводимым в научный оборот источникам из российских архивов. Отрицательные последствия кампании с «сухим законом» 
с самого начала грозили значительно превысить нравственный положительный эффект, подчеркивал он [Мак-Ки, 1999]. Стало расти число случаев, когда крестьяне вместо водки тратили деньги на одежду, предметы, необходимые в сельском хозяйстве. Но это - поверхностный взгляд на проблему. Ведь полного запрета алкогольной продукции не было - $30 \%$ ее приходилось на пиво и вино, а предприимчивые торговцы стали добавлять в эти напитки спирт. Общества трезвости приходили в упадок, волна же спроса на водку находила выход в продаже излишек зерна. Возникали и другие проблемы. В стране рос криминальный паразитический слой самогонщиков, перекупщики, спекулянтов. В итоге «сухой закон усилил ломку налоговой системы» [Петров, 19146, с. 475]. Впрочем, налоговые источники, которые должны были заменить финансовые потери от «сухого закона», не играли существенной роли в затратах на военные расходы по сравнению с денежной эмиссией и государственными займами. Сбор от налогов шел на внутренние дела: компенсация потерь от «сухого закона», содержание государственного аппарата и др. Благодаря введению новых налогов казна выручила к 1916 г. 1052 млн руб. (при общих военных расходах около 30 млрд). Большая часть таких сборов ушла на компенсацию отмены продажи водки. В результате введения «сухого закона) казна теряла около 700 млн руб. чистого годового дохода (по другим показателям - «около миллиарда») [Петров, 19146, с. 475].

Таким образом, царский указ о «сухом законе» опосредованно способствовал инфляции. «Изреченная» невовремя воля царя превращалась в пустой звук за фасадом сложных финансовых проблем военного времени, демонстрируя узость, ограниченность мышления последнего русского самодержца. «Сухой закон» давал «денежные излишки», рождая новые проблемы, добавляя их к другим, связанным с эмиссионной политикой Министерства финансов и правительства. Компенсировать финансовые потери в 1916 г. от непродуманности введения «сухого закона» удалось благодаря резкому повышению других видов налогов за счет народа.

Для сохранения уровня доходов до 4 млрд (3974 млн) в 1916 г. Министерство финансов в войну предприняло ряд мер с увеличением налогов по всем направлениям, введением новых обложений на население. При этом косвенные налоги сохраняли лидерство $(45,5 \%$ от общего их сбора); затем шли прямые налоги (28,2\%), третьим по назначению источником такого рода поступлений в казну были пошлины (26,4 \%) [Петров, 19146, с. 475].

К проблеме сбора налогов в годы Первой мировой войны в России в первое десятилетии XXI века вышли специальные исследования. Это было обусловлено ее актуальностью при начавшемся становлении нового российского государства и нехваткой средств для эффективного развития страны [Толкушкин, 2001; Захаров, Петров, Шацилло, 2006; Чальцева, 2016].

Радикалы социал-демократы еще в Первую мировую войну с удвоенной энергией подчеркивали, что «косвенные налоги, это - налоги на бедных, что «крестьяне и рабочие вместе составляют 9/10 всего населения и платят 9/10 или 8/10 косвенных налогов» [Ленин, 1967, с.172] и требовали от правительства введения прогрессивного налога на доходы и наследство. В годы мировой войны политика правительства в отношении приоритета косвенного обложения отрицательно оценивалась и представителями либеральных политических течений, разоблачавших тяжесть налоговой системы для народа. Замечу, что Т.А. Чальцевой эта сторона налоговой системы убедительно конкретизируется при анализе функционирования системы сахарного акциза в годы войны [Чальцева, 2016].

Первая мировая война раскрыла всю слабость податной системы в России, ее недостаточную гибкость, крайнюю «не уравнительность», хаос с прямым обложением, предельное напряжение со сбором косвенных налогов. Общая картина повышения налогов в России к 1917 г. впечатляет. Еще до конца 1914 г. народ стал расплачиваться за войну стоимостью товаров за счет увеличения ставок обложения по 12 видам косвенных налогов. Даже не пытаясь уравновесить социальные и финансовые проблемы, Министерство финансов потребовало незамедлительно изменить ставки косвенного налогообложения по всем видам косвенных налогов. В первую очередь это было сделано повышением налогов 
на табак (на 25-167\%), на спички (56-100\%), керосин (50\%), сахар (14\%) [Захаров, Петров, Шацилло, 2006, с. 266] - жизненно необходимые населению товары. Повышение налогов столкнулось с быстрым закручиванием спирали дороговизны с конца 1915 г.

В 1915 г. наполовину были повышены ставки промыслового налога, на 50-100\% государственный поземельный налог; на $33 \%$ - на городскую недвижимость, на 40 \% таможенные тарифы. Были введены два новых налога - на хлопок и с железнодорожных грузов, увеличены ставки обложения по всем видам прямых налогов, и даже появился налог на производство телефонных аппаратов [Сабанти, 1985, с. 25, Соколов А.С. 2014, c. 500]. К 1916 г. ставки акцизов (косвенного обложения) были подняты на 100-300\% в зависимости от предмета обложения.

Фискальная политика налогообложения в войну стала острым, сильно возбуждающим общество фактором, она смыкалась с политикой до конца Февральской демократической революции, когда летом 1917 г. в печати горячо обсуждалась тема о несостоятельности налоговой системы, как одной из причин угнетенного состояния трудящихся классов [Имшенецкий, 1917].

Повышение налогов столкнулось с быстрым закручиванием спирали дороговизны еще с конца 1915 г. Протестная реакция была незамедлительной. Повышенные расценки и разного рода военные надбавки к заработной плате в городах не успевали за ростом цен. Стоимость жизни увеличивалась в «разы»; реальная заработная плата все дальше отставала от довоенного уровня. При сушествовавшей угрозе замораживания заработной платы на многих производствах, включая железнодорожников, повышение налогов было не только обременительно, но и грозило тяжелыми последствиями. Налоги в войну коснулись и рабочих на военных предприятиях [История рабочего класса СССР, 1982, с. 265-274].

«Роль инфляционного рычага, призванного изъять из обращения часть эмитированных бумажных денег» [Петров, 2014в, с. 383], стабилизируя финансы, должны были играть внутренние займы. Это был еще один путь имперского правительства по выколачиванию средств у населения. Реализуемые в виде облигаций и других ценных бумаг краткосрочные и долгосрочные займы должны были играть роль политического пиара (паблик рилейшн - PR Б.Н. Миронов ${ }^{1}$ ), ослабляя негативные последствия выпуска бумажных денег. Но запущенные потери покупательной способности рубля настораживали народ все более. Теперь ему было предложено принять участие в другого рода «поддержке правительства) для победы в войне.

История займов в годы Первой мировой войны подробно рассмотрена в диссертации В.Я. Бляхера [Бляхер, 1955], скрупулезно собрана Ю.П. Бокаревым для энциклопедии [Бокарев, 2014, с. 608-613]. По расчетам Министерства финансов до войны, Россия в августе 1914 г. должна была пойти и пошла на крупный внутренний заем путем размещения среди населения около 20 серий билетов Государственного казначейства на сумму 25 млн руб. серия. Обладатель билета этого долгосрочного займа получал 4 \% ежегодного дохода. Билеты предполагалось погасить до августа 1928 г. Собранные 300 тыс. руб. незамедлительно пошли на военные нужды, при том что проблем было немало и на потребительском рынке.

В конце 1914 г. по инициативе самого Барка было принято решение о выпуске еще и 5 \%-го военного займа. Его сумма составляла 500 млн руб. при условия погашения тиражами в течение 49 лет, начиная с 1916 г. (до 1965 г.). Гарантом всей суммы займа выступал на выгодных условиях синдикат во главе с Государственным банком 24 ведущих акционерных коммерческих банков и 5 банковских контор. Это обеспечило успех в проведении займа, дав казне тогда 466 млн руб. [Бокарев, 2014, с. 608-613].

1 Этот термин появился в США в начале ХХ в. Вводя его, Б.Н.Миронов пишет, что историки часто исследуют роль пропаганды и агитации в развитии революции в стране, но редко изучают пиар (PR) как таковой. Эти технологии воздействия на ценности людей имеют цель управлять обществом посредством манипулирования массового сознания [Миронов, 2012, с. 611]. 
В 1915 г. были выпушены новые 4 \%-е билеты Государственного казначейства, но они уже имели меньший успех из-за роста инфляции, которая к тому времени составляла около 30 \%, значительно превышая выплачиваемые годовые проценты [Бокарев, 2014, с. 609].

Министерство финансов, сберегая казну, предпочитало выбираться из сложной финансовой ситуации и на займах у народа. Цифры как нельзя лучше обнажают финансовую ситуацию тяжелой военной ношей страны. До февраля 1917 г. было выпущено еще несколько внутренних военных займов на общую сумму 8 млрд номинальных рублей, чистая выручка от реализации которых составила более 7,5 млрд $(7528,9$ млн). Около половины этой суммы (4033 млн) эмитировал синдикат коммерческих банков Петрограда и Москвы, остальные облигации на 3967 млн руб. были размещены Государственным банком. Ведя активную пропаганду о займах в народе, банк выпустил на собственные средства до 1 млн экземпляров плакатов и около 10 млн экземпляров брошюр. Он предоставлял всем подписавшимся на облигации займов самые различные ссуды вплоть до 75 \% их стоимости, бесплатное хранение и т. п. Но в результате общей полученной суммы от займов Россия покрывала лишь $30 \%$ военных расходов.

Общие суммы внутреннего и внешнего долгов, в которые влезла Россия в войну, расходятся, что объясняется разным учетом внутренних долгов [Петров, 2014в, с. 383]. По подсчетам Ю.А. Петрова, общая государственная задолженность Российской империи к началу 1917 г. достигла 60 млрд руб. Только на уплату процентов по займам она ежегодно тратила 3 млрд руб. - столько же, сколько перед войной составляли все государственные доходы империи. Есть сведения, что долги выросли за время войны в 4,5 раза - с 8,8 до 39,4 млрд руб. [Петров, 2002, с. 221].

Если внешняя задолженность России к началу войны составляла 2,8 млрд долларов (5,5 млрд руб.), то за 1914-1916 гг. внешний долг увеличился на 3696 млрд долларов (до 7,7 млрд руб.), а в начале 1917 г. он составил 12,7 млрд руб. (6,8 млрд долларов) [Бокарев, 2014 , с. 609]. Самой большой была ее внешняя задолженность Великобритании (до 2,7 млрд долларов), в числе государств, предоставлявших деньги России в долг, были Франция, США, Япония, Италия и другие государства.

Изменения в денежном обращении касались миллионов людей, переплетались, смыкались одно с другим, идя одновременно с колоссальными раздражавшими их социальными изменениями. С начала войны в 10 раз выросла армия: с 1,4 млн человек в 1913 г. до 14,2 млн в 1916 г. На фоне новых и новых мобилизаций с каждым месяцем усилился поток людей из деревни в промышленные центры, имевшие потребность в рабочей силе, позволявший выжить лишившейся мужской силы деревне. Численность сельского населения уменьшилась с 113,9 млн человек в 1914 г. до 112,7 млн человек в 1917 г., а в городе росла (вбирая в себя и беженцев): с 25,8 млн в 1914 г. до 29,0 млн в 1916 г. [Бокарев, 2014, с. 609] С каждым месяцем увеличивался спрос населения в городах на продукты и промышленные товары; среди сельского населения продолжалась (и как следствие «сухого закона») расти потребность на товары и предметы первой необходимости.

Имперское правительство в «критический» 1916 г. оказывалось в сжимавшихся финансовых тисках, а это несло угрозу прежде всего гражданскому промышленному производству, всем отраслям народного хозяйства. В предпринимательской среде громко об этом заговорили летом 1916 г., когда пробудился ослабленный в начале войны интерес к дивидендам и к доходам, получаемым от «промышленных бумаг». Сказывался после более менее завершенной военной перестройки всплеск активности на фондовом рынке, которая была все-таки обеспечена напряженной работой Министерства финансов. Обратив внимание на акционерные банки, Ю.А. Петров отметил «непонятное, напряженное положение в финансово-промышленной сфере». Финансовые тиски с трудом преодолевались накачиванием рынка бумажными платежами. Золото использовалось скупо, только во внешней торговле и при уплате процентов на займы, устойчивость рубля снизилась. Тем не менее спрос на дивидендные бумаги, оживлявший операции банков во время предвоенного подъема, 
начался в условиях падения покупательной способности рубля, когда ценные бумаги становились фактором удерживавшим инфляцию [Шепелев, 1963; Петров, 2014в].

Оставалось успокоить народ. Возникали разные проекты, вплоть до планирования заказа на чеканку в Японии никелевых монет, похожих на серебряные. Появился и указ о налоге с предприятий и лиц, доходы и прибыль которых существенно выросли благодаря военным заказам.

Пытаясь приостановить растущую «дыру» в бюджете, связанную в том числе с компенсационной политикой правительства, платившего деревне деньгами за каждого взятого в армию работника (а также с потерями к тому времени около 1 млрд руб. от ранее поступавших доходов от реализации алкогольных напитков) государство решилось на введение подоходного налога и прежде всего - с «банкирского промысла». Возникало опасение подъема протестного движения в связи с растущим неравенством от распределения доходов. От банкирских заведений Министерство финансов потребовало представить балансовые данные на 1-е число июля в 1914, 1915, 1916 гг. Однако далеко не все банки откликнулись на 291 опросный лист. Ведь в начале войны некоторые банкирские заведения резко сократили операции, но стали восстанавливаться в связи с появлением на рынке свободных средств лишь в 1916 г. Свободный капитал, не находивший из-за условий войны другого помещения, устремился в сферу банковских операций [Лизунов, 2014а].

Вопрос о рождении проекта о введении подоходного налога в высших органах власти был странным образом забыт в исторической литературе. После небольшой статьи Г.И. Болдырева 1924 г. историю о введении подоходного налога в годы Первой мировой войны пришлось ждать до 1986 г. и статьи А.Н. Боханова [Боханов, 1986]. Независимо от него к теме подоходного налога в 1999 г. обратился и американский исследователь Я. Коцонис.

Замечу, что у подоходного налога был более широкий «идеологический и политический подтекст»: введение подоходного налога в налоговой реформе стало возможно в дореволюционной России потому, что «имперскую власть толкнуло на это общество», и это не лишено правды. Налоговая реформа, закончившаяся принятием закона о подоходном налоге, была одной из самых крупных, предпринятых царским правительством в последние годы Российской империи, но лишь за 10 месяцев до ее падения [Коцонис, 1999, c. 472]. В этом возможно видеть, как заметил А.Н. Кураев, то самое проявление элементов «плюрализма демократии». Она проявляется в многообразии общественных интересов, способных оказывать «скрытое давление» на власть» [Кураев, 2006, с. 150]. Подтверждается это долгим прохождением закона. Проект подоходного налога осуждался еще во II-ой и III-ей Государственных думах. В IV-ой Думе на третий год войны он вышел за пределы ее Финансовой комиссии; тогда принятие закона о подоходном налоге стимулировало напряженное положение в стране с финансами (потеря доходов после принятия «сухого закона» - продажи водки и др.) [Коцонис, 1999, с. 474-476].

Стоит отметить, что проект закона прошел через Государственную думу и был поддержан оппозицией еще в августе 1915 г. После этого процесс налогообложения, в котором главным был подоходный налог, долго «проникал в тело» российского общества и достиг кульминации в 1916 г.

В проекте присутствовал жесткий язык гражданственности (доказательство движения общества по пути демократии), хотя и «с неожиданными поворотами в ходе обсуждения), на которые указывает Я. Коцонис, и видит в принятии подоходного налога движение России к гражданскому обществу [Коцонис, 1999, с. 476].

При обсуждении этого проекта закона (в течении не одного года!) низший порог обложения условно связывался с «прожиточным минимумом» и в спорах при обсуждении колебался от 1000 до 750 руб. годового дохода. В конечном счете, он был определен в 850 руб. годового дохода, «избавив (тем самым) от подоходного налога примерно половину российских семей» [Коцонис, 1999, с. 474]. Максимальная ставка обложения утверждалась в пределах $12 \%$. Доходы сверх 400 тыс. должны были облагаться по схеме: плюс 
1250 руб. с каждых 10 тыс. излишка. Для некоторых категорий населения допускались послабления (офицеры, солдаты действующей армии). Плательщик должен был в Присутствии заявить о своих доходах, и это учреждение должно было провести проверку об окладных суммах налога [Буланже, 1998, с. 147-151, Захаров, Петров, Шацилло, 2006, с. 319-324, Петров Ю.А. 19146, с. 475-476; Селезнев, 2014, с. 749]. Информация в соответствующем учреждении о собственной экономической деятельности предполагала, что плательщик будет исходить из чувства гражданского долга, а не повиноваться авторитету и силе государства [Коцонис, 1999, с. 470].

Нельзя не обратить внимания, заметил Я. Коцонис, на прежнюю тенденцию при обсуждении проекта закона. В обсуждении явно была попытка давления царской бюрократии на те стороны проекта, которые при издании закона заставили бы еще больше «выкладываться» и тяжесть нового налога переложить на «крестьян, как на самый беззащитный и безгласный класс и потому легко поддающийся эксплуатации». Так было всегда, хотя в высших сферах находились сторонники «здравого смысла», если вспомнить С.Ю. Витте. Он считал, что сначала нужно сделать крестьянина обеспеченным, способным платить налоги [Россия и Первая мировая война..., 1999, с. 512]. При обсуждении подоходного налога в 1916 г. в высших сферах «игры» с низшим уровнем обложения сопровождались упреками в отклонении уплаты налогов «нищей части страны», она попутно обвинялась в «некультурности», «отсутствии гражданственности» [Коцонис, 1999, с. 470].

Закон о подоходном налоге был подписан Николаем II 6 апреля 1916 г. Он затрагивал интересы крупной буржуазии, а также средних слоев населения, на что указывала вся раскладная система обложения. Предполагалось, что он должен был вступить в силу в 1917 г.

Замечу, что историки не нашли ответа на вопрос об отношении к проекту самого Николая II, но все же он поставил свою подпись. Будем считать, что одобрил усилия Министерства финансов в поисках новых резервов для пополнения бюджета в годы войны. Одно можно сказать: это решение было вызвано безвыходным положением царского правительства, связанным с возросшей политизацией широких слоев общества.

В правящих кругах имперской России тогда опасались внутренних протестов лиц, которым нужно было платить подоходный налог, колебались, стремились сделать его достаточно эффективным в тех пределах, которые предусматривались законом. В одном из циркулярных писем, направленных управляющим казенными палатами в самом начале 1917 г., П.Л. Барк персонально призывал к «снисходительному отношению к плательщикам со стороны финансового ведомства» [Боханов, 1986, с. 299]. Интересно было бы знать, на какую сумму для пополнения бюджета рассчитывало правительство введением подоходного налога?

Реализация проекта о подоходном налоге предполагала издание закона в 1917 г., но не была завершена до 3 марта 1917 г. Временному правительству была расчищена дорога для удовлетворения «настроений бушевавшей демократии». Забегая вперед, замечу, что министры-кадеты не особенно торопились с обложением обеспеченных и богатых слов общества.

С начала войны усилия Министерства финансов шли под лозунгом работы на «оборону», а это фактически означало открытие возможности крупным предпринимателям получать огромные прибыли благодаря гигантским правительственным военным заказам. Это происходило при росте внутренних цен на продукты и товары первой необходимости при набиравшем обороты обесценивании бумажного рубляя.

А.Л. Сидоров, а затем Ю.А. Петров, в целом принявший его научную концепцию, показали, как инфляция и рост товарных цен привели к невиданному росту банковских пассивов, как шло накопление банками капиталов [Сидоров, 1960, с. 407, Петров, 2014в, с. 392]. Их труды дополнены исследованиями Л.Е. Шепелева [Шепелев, 1963, с. 156-193] и других историков об акционерных коммерческих банках. Эти труды показали, что к 1917 г. их вклады в текущие счета с 2,5 млрд руб. в 1914 г. поднялись до 6,7 млрд. Но с оживлением банковской системы в войну шло обескровливание страны, увеличение то- 
варного дефицита, расстройство транспорта и т. д. Доходы богатеющих банкиров и предпринимателей выросли, но неравенство росло как болезнь общества, бедняки становились беднее. Рецепты спасения беднеющего населения не обсуждались, если не считать слабого голоса общественности в 1916 г. - во время обсуждений введения прогрессивного налога.

Имперское государство в войну сосредоточило в своих руках важнейшие товарнораспорядительные функции. Торговля все чаще переходила к сделкам на наличные деньги, вексельное обращение снижалось. Резкий скачок в товарно-судной сфере приносил доход тем, кто умел быстро приспособиться к изменившейся обстановке, к иным экономическим отношениям, где рост цен давал большие прибыли. Не совсем ясно, куда шла при этом кривая доходов среднего слоя предпринимателей при военных пертурбациях, как колебалось финансовое состояние этого слоя?

Сегодня в трудах по истории финансов в Первую мировую войну внимание привлекается к финансовой сфере, где обычной практикой становилось представление клиентам в распоряжение банка в обмен на кредит партии товаров для комиссионной продажи, прибыль от которой оседала в кассе банках. Зависимые от учреждений коммерческого кредита торговые фирмы зачастую превращались в товарные отделы банков, использовались в качестве подставных кампаний при оформлении товарных сделок. На сахаре, хлопке, угле и других товарах массового потребления многие банки также в войну получали огромные барыши. Но было бы неправильно, пишет Ю.А. Петров, останавливаться только на этом, отправляя русский капитал на скамью подсудимых только за его обогащение, как это делала вся советская литература, Определенное число крупных капиталистов, получая прибыль в годы мировой войны, использовали ее создание новых перспективных производств. Эта сторона истории финансов не должна уходить в тень. Война здесь выступает, не как противоестественное состояние общества, а как фактор проявления возможного потенциала промышленного производства при наличии капитала. Так, семейство талантливых предпринимателей Рябушинских, опираясь на прибыль своего Московского акционерного коммерческого банка, сумело-таки заложить уже в феврале 1916 г. ряд отечественных производств (основу автомобильного завода в Москве фирмы АMO, просуществовавшего до развала СССР в 90-е гг.), организовать экспорт русского льна за границу, лесообрабатывающий завод, предприятие стекольного производства [Петров, 2014в]. В.В. Поликарпов указал на скачок, который сделало военное производство в годы войны, создав основу важнейших отраслей промышленности (производство самолетов, разного рода двигателей, оптического стекла и приборов и т. д.) [Поликарпов, 2015].

Всевластие банков в войну оказалось полезным промышленности. Они вместе с тем страховали казну от риска оказаться в убытке при несостоятельности подрядчиков, хотя в условиях инфляционного денежного наплыва военных лет здесь все оказалось чрезвычайно запутанным, что и подчеркивается в историографии.

В годы военного напряжения в финансовой сфере России проявился ряд тенденций, связанных с финансовой олигархией, иных по сравнению с тем, что было ранее. К началу войны основные звенья системы финансового капитала сложились и находились «как бы в состоянии покоя». Начавшийся после 1908 г. промышленный подъем вывел их из этого состояния. Продолжая эту мысль, можно сказать, что «при ослаблении позиций иностранного капитала в экономике страны подъем военного производства давал основание для превращения российского финансового капитала в «вполне зрелый вид» [Бовыкин, 1984, с. 247-248].

Новое прочтение источников по этим проблемам продолжило историю вторжения в банковское дело новых финансовых групп отечественного происхождения. Эти группы, к сожалению, если и не активно враждовали между собой, то относились друг к другу с подозрением. Опережающим темпом развивалась московская группа банков, но господствующие позиции продолжала сохранять за собой петроградская [Петров, 2014в, Палеолог, 1991]. К концу 1916 г. обе финансовые группы на фоне надвигавшихся в обществе политических перемен (их хорошо чувствовали прозорливые отечественные финансисты) 
не стремились к сглаживанию противоречий, продолжая враждовать между собой, внося свой «вклад» в общественный хаос. Финансовую систему разрушали стихия, беспорядок, хаос в обществе военного происхождения, мешая становлению капиталистической модернизации страны.

Несмотря на все трудности на третий год войны осенью 1916 г. Министерство финансов пришло к заключению, что фондовый рынок настолько окреп и, невзирая на войну, возникает возможность открыть фондовую биржу торговли ценных бумаг. Об этом, убеждая в стабильности курса рубля, написала «Торгово-промышленная газета» [Торговопромышленная газета. 1917. 12 января - 26 февраля]. 24 января 1917 г. после официально открытого фондового отдела в Петербургскую (Петроградскую) биржу приехали: П.Л. Барк, товарищ министра финансов С.А. Штаден, директор Кредитной канцелярии К.Е. Замен и другие важные особы ведомственного мира [Лизунов, 20146, с. 485].

В феврале началось резкое колебание цен на русские фонды, акции и облигации, а то, что творилось 8 февраля 1917 г. на Петроградской бирже, описал экономист профессор П.П. Мигулин: «В Петрограде тревожно. Мы живем как в пиру во время чумы... На бирже вакханалия. Бедные люди в 1-2 недели делаются богатыми, но все идет на повышение. В результате может быть крах, но может и не быть. Уж очень много выпущено в оборот бумажных денег, и все товары, земли и дивидендные ценности должны повыситься в расценке. Но все это печально. Никто не думает о войне, о военных займах, каждый стал заботиться о себе: «Спасайся; кто может» [Родина, 1999. 11: 21-22].

Биржевые хроникеры в репортажах отмечали особый мир скопления людей, «многие из которых не могли протиснуться в зал, отведенный для сделок, и теснятся в прихожей», удивленных от неожиданного появления «американских размеров» сделок, большинство из которых совершалось за наличные [Биржевой курьер. 1917. 25 января].

Биржевой ажиотаж из столицы перекинулся в Харьков, Одессу, Киев. Финансовый капитализм побеждал в рассыпном строю в условиях свободной конкуренции и ожиданий удач. Но ощущение нажитой собственности у в общем-то небольшой в России социальной группы людей было очень зыбким. Они в связи с падением рубля, с одной стороны, боялись потерять нажитое, а с другой, не воспользоваться моментом, удачей и увеличить капитал. Телеграф не успевал отправлять срочные телеграммы, подаваемые местными банковскими отделениями в Петроград и Москву на покупку различных бумаг.

Петербургская биржа не стала экономическим барометром жизни страны. Промышленность пребывала в крайне тяжелом состоянии, заводы закрывались, в том числе крупнейший в столице и в стране Путиловский. Само положение банков было угрожающим: их портфели были обременены биржевыми ценностями, вздутыми до совершенно фантастических цен.

В февральские дни 1917 г. финансовая лихорадка с набережной р. Невы, где находилась биржа, распространялась в городе в определенных кругах. К ней проявлялся «коллективный» интерес среднего класса, поднимая его настроение, усиливалось противостояние полюсов расколотого войной общества. Но общественная жизнь распорядилась соединить тревогу по поводу обесценивания рубля, претензии к имперскому правительству с демонстрациями рабочих и солдатским политическим бунтом на улицах столицы. 23 февраля, несмотря на толпы народа, пробившиеся в центр столицы, на Петроградской бирже господствовало положительное сальдо, но уже два последующих собрания 24 и 25 февраля сопровождались значительным понижением курсов [Лизунов, 2014в, с. 691].

Созревание чего-то огромного и пока не понятного в Петрограде чувствовали в своих дипломатических апартаментах иностранные послы и журналисты, пророчившие «скорую революцию», которая «ждет только повода, чтобы вспыхнуть». За два месяца до революции председатель Совета фондового отдела Петербургской биржи, банкир, А.И. Путилов в беседе с французским послом М. Палеологом говорил: «Поводом может послужить военная неудача, народный голод, стачка в Петрограде, мятеж в Москве, дворцовый скандал... все равно» [Палеолог, 1991, с. 179]. Может быть, в глубине души он не 
ожидал, что его пророчество сбудется так скоро [Петров, 2014в, с. 395], с иронией процитировал этот отрывок впоследствии историк.

Накануне революционного взрыва в функционировании всей государственной системы существовали разные противоречия, были и заторы в виде бумажной массы. Каждый день ведения войны стоил России от 30 до 50 млн руб. На первую цифру указывает помощник управляющего Советом министров в 1914-1916 гг. А.Н. Яхонтов [Совет Министров Российской Империи, 1999, с. 41]; вторая - названа А.Л. Сидоровым [Китанина, 2016, c. 307].

Несмотря на усилия Министерства финансов (выпуск внутренних займов на сумму в 10,5 млрд руб., повышение насколько возможно косвенных налогов, и даже увеличение государственного дохода с $35 \%$ в 1913 г. до $53 \%$ в 1917 г.) два с половиной года войны не прошли без ущерба для финансовой системы. Военный бюджет в 1916 г., достигший 25 млрд руб., с трудом покрывался на 10 млрд казной и внутренними займами, на 7 - зарубежными кредитами (5,5 млрд предоставила Англия) [Никонов, 2011, с. 410-415]. К тому же эти показатели оставляют в стороне расходную часть бюджета для тыла.

В денежном обращении сами по себе развивались процессы, которые вели к безудержной инфляции. Параллельно с социально-политическими конфликтами власти и общества в другой его сфере под угрозой оказывались перспективы деловой работы государственных банков, в общем, вся финансовая система, будущее страны. Не совладав с печатным станком, имперская власть обрекала себя на недоверие широких масс, тащивших на себе ценой огромных потерь (к 1917 г. - 1,7 млн жизней, 3,7 млн раненых и искалеченных, 3,3 млн в плену) «защиту отечества» - тяжелый груз войны. Этих цифр тогда никто не знал, но за ними было море слез и семейного горя.

Ажиотаж вокруг дивидендных ценностей в России мало кого касался. Подавляющее большинство населения к 1917 г, особенно в городах, при избытке бумажных денег все больше испытывало недостаток товаров и рост дороговизны. Наполнение оборота в стране бумажными деньгами к тому же стимулировало гиперинфляцию, нарушение производственных и торговых связей, смыкалось с разрушением традиционных рыночных отношений.

Замечу, что некоторые историки склоняются к тому, что была возможна альтернатива революции, что страна укрепилась к 1917 г. в военном отношении, а финансы ее находились «в относительно удовлетворительном для времени состоянии» [Никонов, 2011, c. 415]. Приведенный в статье материал дополняет другие выводы о внутреннем состоянии страны. Относительно удовлетворительное состояние финансов могло быть, но временным, в короткие периоды за тридцать месяцев войны. Воздавая должное усилиям Министерства финансов и лично П.Л. Барку, можно сказать, что в действительности и финансовое положение оказалось катастрофичным для страны. Решать финансовые проблемы с учетом социально-экономических Министерству финансов приходилось в одной упряжке с деморализованным государственным аппаратом, при «упадке духа»в стране, дисциплины, морального разложения, падения нравов в обществе

В наиболее правильное определение ситуации в стране с начала февраля 1917 г. его шаткость, растерянность на финансовом рынке [Петров, 2014в, с. 393-394]. Российские биржевики и их партнеры в сфере финансов не научились собственной деловитости. Понимая экономическую и политическую конъюнктуру, они закрывались от политики, но боялись грядущих перемен.

Известно политическое завещание М. Рябушинского, в котором он размышлял о «надвигающемся хаосе», хорошо зная шаткое состояние финансовой системы, симптомы которого проступали в российской действительности. Российский олигарх с горечью писал в канун Февральской революции: «Мы переживаем трагическое время, и декабрь 1916 года в истории России навсегда оставит память противоположности интересов родины и правительства. Будущее темно...» [Рябушинский, 1954, с. 610-633]. 
Выход из положения решила революция. Демонстрации в центре столицы приостановили 27 февраля 1917 г. биржевые сделки; через четыре дня биржа закрылась. До 3 марта, когда Временным комитетом Государственной думы и Петроградским Советом рабочих и солдатских депутатов решался вопрос о власти, населением в сберегательных кассах было изъято 1,1 млн руб. [Петров, 2007, с. 162]

1 марта П.Л. Барк, с именем которого связан труднейший период управления финансами в годы войны, был арестован своим бывшим лакеем (ему Барк ранее помог избежать отправки на фронт). Содержался Барк в Министерском павильоне Государственной думы вместе с другими царскими министрами; 5 марта 1917 г. был освобожден и вскоре выехал с семьей на юг России.

Управление финансами перешло Временному правительству.

\section{Список литературы References}

1. Биржевой курьер. 1917. 25 января.

Birzhevoj kur'er. 1917. 25 yanvarya.

2. Бляхер В.Я. 1955. Государственные займы дореволюционной России и их аннулирование Советским правительством. Дисс... канд. эконом. наук. М., 327.

BlyaherV.Ya. 1955. Gosudarstvennye zajmy dorevolyucionnoj Rossii i ih annulirovanie Sovetskim pravitel'stvom. Diss... kand. ekonom. nauk. M., 327.

3. Бовыкин В.И. 1984. Формирование финансового капитала в России. Конец XIX - 1908 г. М., Наука, 287.

Bovykin V.I. 1984. Formirovanie finansovogo kapitala v Rossii. Konec XIX - 1908 g. M., Nauka, 287. (inRussian)

4. Бокарев Ю.П. 2014. Денежное обращение. В кн.: Россия в Первой мировой войне 19141918. Энциклопедия в 3-х т. Отв. ред. А.К. Сорокин.М., РОССПЭН, Т. 1.: 608-613.

Bokarev YU.P. 2014. Denezhnoe obrashchenie. V kn.: Rossiya v Pervoj mirovoj vojne 19141918. Enciklopediya v 3-h t. Otv. red. A.K.Sorokin. M., ROSSPEN, T. 1.: 608-613. (inRussian)

5. Боханов А.Н. 1986. Вопрос о подоходном налоге в России и крупная буржуазия (конец XIX - начало XX в.). В кн.: Исторические записки. 114: 276-302.

Bohanov A.N. 1986. Vopros o podohodnom naloge v Rossii i krupnaya burzhuaziya (konec XIX - nachalo HH v.). V kn.: Istoricheskie zapiski. 114: 276-302.

6. Буланже М. 1998. Из истории подоходного налога и налога на прибыль В кн.: Налоговый вестник. 6: 147-151. $147-151$.

Bulanzhe M. 1998. Iz istorii podohodnogo naloga i naloga na pribyl' V kn.: Nalogovyj vestnik. 6 :

7. Дьячков А.Н., Челноков В.А. 1974. Финансы в дореволюционной России и в СССР. В кн.: Советская историческая энциклопедия. В 16 тт. Главный редактор Е.М. Жуков. М., Советская энциклопедия, Т. 15: 138.

D'yachkovA.N., CHelnokovV.A. 1974. Finansy v dorevolyucionnoj Rossii i v SSSR. V kn.: Covetskaya istoricheskaya enciklopediya. V 16 tt. Glavnyj redaktor E.M. Zhukov. M., Sovetskaya enciklopediya, T. 15: 138. (in Russian)

8. Захаров В.Н., Петров Ю.А., Шацилло М.К. 2006. История налогов в России. IX - начало ХХ в. М., РОССПЭН, 296.

Zaharov V.N., Petrov Yu.A., Shacillo M.K. 2006. Istoriya nalogov v Rossii. IX - nachalo XX v. M., ROSSPEN, 296.

9. Имшенецкий Б. 1917. Несостоятельность дореволюционной налоговойсистемы: Одна из причин угнет. состояния трудящихся классов. Киев, Рев. мысль, 32.

Imsheneckij B. 1917. Nesostoyatel'nost' dorevolyucionnoj nalogovoj sistemy: Odna iz prichin ugnet. sostoyaniya trudyashchihsya klassov. Kiev, Rev. mysl', 32. Наука, 464.

10. История рабочего класса СССР. 1982. Рабочий класс России 1907 - февраль 1917 г. М.,

Istoriya rabochego klassa SSSR. 1982. Rabochij klass Rossii 1907 - fevral' 1917 g. M., Nauka, 464.

11. Китанина Т.М. 2003. Россия в первой мировой войне. 1914-1917 гг. Экономика и экономическая политика: в 2 ч. СПб., Издательство Санкт-Петербургского университета, Ч.1: 144. 
Kitanina T.M. 2003. Rossiya v pervoj mirovoj vojne. 1914-1917 gg. Ekonomika i ekonomicheskaya politika: v 2 ch. SPb., Izdatel'stvo Sankt-Peterburgskogo universiteta, Ch.1: 144

12. Китанина Т.М. 2016. Россия в первой мировой войне. Экономика и экономическая политика. 1914-1917 гг. Курс лекций. Изд. 2-ое. СПб., Гуманитарная академия, 348.

KitaninaT.M. 2016. Rossiya v pervoj mirovoj vojne. Ehkonomika i ehkonomicheskaya politika. 1914-1917 gg. Kurs lekcij. Izd. 2-oe. SPb., Gumanitarnaya akademiya, 348. (in Russian)

13. Коцонис Я. 1999. Подданный и гражданин: налогообложение в Российской империи и в Советской России и его подтекст. В кн.: Россия и Первая мировая война. Материалы международного научного коллоквиума. Отв. ред. Н.Н. Смирнов. 1999. СПб., Дмитрий Буланин, 467-481.

Koconis Ya. 1999. Poddannyj i grazhdanin: nalogooblozhenie v Rossij-skoj imperii i v Sovetskoj Rossii i ego podtekst. V kn.: Rossiya i Pervaya mirovaya vojna. Materialy mezhdunarodnogo nauchnogo kollokviuma. Otv. red. N.N.Smirnov. 1999. SPb., Dmitrij Bulanin, 467-481.

14. Кравцова Е.С. 2003. Проблемы перехода к подоходному налогообложению в России в период Первой мировой войны. В кн.: Россия в первой мировой войне. Экономика и экономическая политика. Ч. 1, 2. СПб., 502-508.

Kravcova E.S. 2003. Problemy perekhoda k podohodnomu nalogooblozheniyu v Rossii v period Pervoj mirovoj vojny. V kn.: Rossiya v pervoj mirovoj vojne. Ehkonomika i ehkonomicheskaya politika. CH. 1.2. SPb. 502-508. (in Russian)

РГГУ, 194.

15. Кураев А.Н. 2006. Риски демократических систем власти. М., Институт проблем риска

Kuraev A.N. 2006. Riski demokraticheskih sistem vlasti. M., Institut problem riska RGGU, 194.

16. Ленин В.И. 1967. К деревенской бедноте. В кн.: Ленин В.И. Полное собрание сочинений. Т.7. М., Издательство политической литературы: 129-203.

Lenin V.I. 1967. K derevenskoj bednote. V kn.: Lenin V.I. Polnoe sobranie sochinenij. T.7. M., Izdatel'stvo politicheskoj literatury: 129-203.

17. Лизунов П.В. 2014а. Банкирские заведения. В кн.: Россия в Первой мировой войне 1914-1918. Энциклопедия в 3-х т. Отв. ред. А.К. Сорокин. М., РОССПЭН, Т. 1.: 120-121.

Lizunov P.V. 2014a. Bankirskie zavedeniya. V kn.: Rossiya v Pervoj mirovoj vojne 1914-1918. Enciklopediya v 3-h t. Otv. red. A.K.Sorokin. M., ROSSPEN, T. 1.: 120-121. (inRussian

18. Лизунов П.В. 2014б. Биржи России и Европы в годы Первой мировой войны. В кн.: Россия в годы Первой мировой войны. Материалы Международной научной конференции (Москва 30 сентября - 3 октября 2014 г). Отв. ред.: А.Н. Артизов, А.К. Левыкин, Ю.А. Петров. М., ИРИ РАН: 478-487.

Lizunov P.V. 2014b. Birzhi Rossii I Evropy v gody Pervoj mirovoj vojny. V kn.: Rossiya v gody Pervoj mirovoj vojny. Materialy Mezhdunarodnoj nauchnoj kon-ferencii (Moskva 30 sentyabrya - 3 oktyabrya 2014 g). Otv. red.: A.N. Artizov, A.K. Levykin, Yu.A. Petrov. M., IRI RAN: 478-487.

19. Лизунов П.В. 2014в. Петербургская биржа. В кн.: Россия 1914-1918. Энциклопедия. Т. 2. М., Политическая энциклопедия: 691.

Lizunov P.V. 2014v. Peterburgskaya birzha. V kn.: Rossiya 1914-1918. Enciklopediya. T. 2. M., Politicheskaya enciklopediya: 691.

20. Мак-Ки А. 1999. Сухой закон в годы Первой мировой войны: причина, концепции и последствия введения сухого закона в России (1914-1917) В кн.: Россия и Первая мировая война. Материалы Международного научного коллоквиума. СПб., Дмитрий Буланин: 147-159.

Mak-Ki A. 1999. Suhoj zakon v gody Pervoj mirovoj vojny: prichina, koncepcii i posledstviya vvedeniya suhogo zakona v Rossii (1914-1917) V kn.: Rossiya i Pervaya mirovaya vojna. MaterialyMezhdunarodnogonauchnogokollokviuma. SPb., DmitrijBulanin: 147-159. (inRussian)

21. Миронов Б.Н. 2012. Благосостояние населения и революции в имперской России. XVIII - начало XX века. М., Весь Мир, 844.

MironovB.N. 2012. Blagosostoyanie naseleniya i revolyucii v imperskoj Rossii. XVIII - nachalo XX veka. M., Ves' Mir, 844. (in Russian)

22. Миронов Б.Н. 2010. Наблюдался ли в России мальтузианский кризис? Доходы и повинности российского крестьянства в 1801-1914 гг. В кн.: О причинах русской революции. Отв. ред. Л.Е. Гринин, А.В. Коротаев, С.Ю. Малков. М., Издательство ЛКИ: 61-111.

Mironov B.N. 2010. Nablyudalsya li v Rossii mal'tuzianskij krizis? Dohody i povinnosti rossijskogo krest'yanstva v 1801-1914 gg. V kn.: O prichinah russkoj revolyucii. Otv. red. L.E. Grinin, A.V. Korotaev, S.Yu. Malkov. M., Izdatel'stvo LKI: 61-111. 
23. Никонов В.А. 2011. Крушение России. 1917. М., АСТ, Астрель. Минск. Харвест, 932.

Nikonov V.A. 2011. KrushenieRossii. 1917. M., AST, Astrel'. Minsk. Harvest, 932. (in Russian) ния, 241

24. Палеолог М. 1991. Царская Россия во время мировой войны. М., Междунар. отноше-

Paleolog M. 1991. Carskaya Rossiya vo vremya mirovoj vojny. M., Mezhdunar. otnosheniya, 241.

25. Петров Ю.А. 2002. Государственный долг России в начале XX в. В кн.: История Министерства финансов России: в 4 т. Т. 1. 1903-1917 гг. Гл. ред. А.Л. Кудрин. М., ИНФРА-М: 211-221.

Petrov Yu.A. 2002. Gosudarstvennyj dolg Rossii v nachale XX v. V kn.: Istoriya Ministerstva finansov Rossii: v 4 t. T. 1. 1903-1917 gg. Gl. red. A.L. Kudrin. M., INFRA-M: 211-221.

26. Петров Ю.А. 2014а. Заем свободы. В кн.: Россия в Первой мировой войне 1914-1918 Энциклопедия в 3-х т. Отв. ред. А.К. Сорокин.М., РОССПЭН, Т. 1.: 704.

Petrov Yu.A. 2014a. Zaem svobody. V kn.: Rossiya v Pervoj mirovoj vojne 1914-1918. Enciklopediya v 3-h t. Otv. red. A.K. Sorokin. M., ROSSPEN, T. 1.: 704. (inRussian)

27. Петров Ю.А. 1914б. Налоги. В кн.: Россия в Первой мировой войне 1914-1918. Энциклопедия в 3-х т. Отв. ред. А.К.Сорокин.М., РОССПЭН, Т. 2.: 475-475.

Petrov Yu.A. 1914b. Nalogi. V kn.: Rossiya v Pervoj mirovoj vojne 1914-1918. Enciklopediya v 3-h t. Otv. red. A.K.Sorokin. M., ROSSPEN, T. 2.: 475-475. (inRussian)

28. Петров Ю.А. 2014в. Финансовое положение до Февраля 1917 г. В кн.: Россия в годы Первой мировой войны: экономическое положение, социальные процессы, политический кризис. Коллективная монография. Отв. ред. Ю.А. Петров. М., Политическая энциклопедия, 379-398.

Petrov Yu.A. 2014v. Finansovoe polozhenie do Fevralya 1917 g. V kn.: Rossiya v gody Pervoj mirovoj vojny: ehkonomicheskoe polozhenie, social'nye processy, politicheskij krizis. Kollektivnaya monografiya. Otv. red. Yu.A. Petrov. M., Politicheskaya enciklopediya, 379-398. (inRussian)

29. Петров Ю.А. 2007. Сберегательные кассы во время Первой мировой войны. В кн.: История сберегательных касс России. 1841-1991. Под ред. А.И. Казьмина. М., б/издательства: 160-169.

Petrov Yu.A. 2007. Sberegatel'nye kassy vo vremya Pervoj mirovoj vojny. V kn.: Istoriya sberegatel'nyh kass Rossii. 1841-1991. Pod red. A.I. Kaz'mina. M., b/izdatel'stva: 160-169.

30. Поликарпов В.В. 2015. Русская военно-промышленная политика. 1914-1917 гг. Государственные задачи и частные интересы. М., Центрполиграф 382.

Polikarpov V.V. 2015. Russkayavoenno-promyshlennayapolitika. 1914-1917 gg. Gosudarstvennye zadachi i chastnye interesy. M., Centrpoligraf 382

31. Родина. 1999. 11: 21-22.

Rodina. 1999. 11: 21-22.

32. Россия и Первая мировая война. Материалы международного научного коллоквиума. Отв. ред. Н.Н. Смирнов. 1999. СПб., Дмитрий Буланин, 553.

Rossiya i Pervaya mirovaya vojna. Materialy mezhdunarodnogo nauchnogo kollokviuma. Otv. red. N.N. Smirnov. 1999. SPb., Dmitrij Bulanin, 533. (inRussian)

33. Рябушинский М.П. 1954. Цель нашей работы. В кн.: К истории концерна Рябушинских. Материалы к истории СССР. Документы по истории капитализма в России. М., 610-633.

Ryabushinskij M.P. 1954. Cel' nashej raboty. V kn.: K istorii koncerna Ryabushinskih. Materialy

$\mathrm{k}$ istorii SSSR. Dokumenty po istorii kapitalizma v Rossii. M., 610-633.

34. Сабанти Б.М. 1985. История финансов России Л., ЛФЭИ, 78.

Sabanti B.M. 1985. Istoriya finansov Rossii L., LFEI, 78.

35. Селезнев Ф.А. 2014. Подоходный налог. В кн.: Россия в Первой мировой войне 19141918. Энциклопедия. М., Политическая энциклопедия, Т. 2: 749.

Seleznev F.A. 2014. Podohodnyj nalog. V kn.: Rossiya v Pervoj mirovoj vojne 1914-1918. Enciklopediya. M., Politicheskaya enciklopediya, T. 2: 749.

36. Сидоров А.Л. 1960. Финансовое положение России в годы Первой мировой войны. (1914-1917). М., Изд-во АН СССР, 579

Sidorov A.L. 1960. Finansovoe polozhenie Rossii v gody Pervoj mirovoj vojny. (1914-1917). M., Izd-vo AN SSSR, 579. (inRussian)

37. Совет министров Российской империи в годы Первой мировой войны: Бумаги А.Н. Яхонтова: Записи заседаний и переписка. Сост. и коммент. Р.Ш. Ганелина, С.В. Куликова, В.В. Лапина, М.Ф. Флоринского и др. 1999. СПб., Дмитрий Буланин, 559

Sovet ministrov Rossijskoj imperii v gody Pervoj mirovoj vojny: Bumagi A.N. Yahontova: Zapisi zasedanij I perepiska. Sost. i komment. R.Sh. Ganelina, S.V. Kulikova, V.V. Lapina, M.F. Florinskogo i dr. 1999. SPb., Dmitrij Bulanin, 559. 
38. Соколов А.С. 2014. Денежное обращение России в 1914 - марте 1917 г. В кн.: Россия в годы Первой мировой войны. Материалы Международной научной конференции (Москва 30 сентября - 3 октября 2014 г). Отв. ред.: А.Н. Артизов, А.К. Левыкин, Ю.А. Петров. М., ИРИ РАН: 499-502.

Sokolov A.S. 2014. Denezhnoe obrashchenie Rossii v 1914 - marte 1917 g. V kn.: Rossiya v gody Pervoj mirovojvojny. Materialy Mezhdunarodnoj nauchnoj konferencii (Moskva 30 sentyabrya - 3 oktyabrya 2014 g). Otv. red.: A.N. Artizov, A.K. Levykin, Yu.A. Petrov. M., IRI RAN: 499-502. (in Russian)

39. Танирова Н.Ф. 2014. Процесс разрушения аграрного рынка и его последствия для сельского хозяйства. В кн.: Россия в годы Первой мировой войны. Материалы Международной научной конференции (Москва 30 сентября - 3 октября 2014 г). Отв. ред.: А.Н. Артизов, А.К. Левыкин, Ю.А. Петров. М., ИРИ РАН: 446-455.

Tanirova N.F. 2014. Process razrusheniya agrarnogo rynka iego po-sledstviya dlya sel'skogo hozyajstva. V kn.: Rossiya v gody Pervoj mirovoj vojny. Materialy Mezhdunarodnoj nauchnoj konferencii (Moskva 30 sentyabrya -3 oktyabrya 2014 g). Otv. red.: A.N. Artizov, A.K. Levykin, Yu.A. Petrov. M., IRI RAN: 446-455.

40. Толкушкин А.В. 2001. История налогов в России. М., Юристъ, 432.

Tolkushkin A.V. 2001. Istoriya nalogov v Rossii. M., Yurist", 432.

41. Торгово-промышленная газета. 1917. 12 января-26 февраля.

Torgovo-promyshlennaya gazeta. 1917. 12 yanvarya-26 fevralya.

42. Труды местных комитетов о нуждах сельскохозяйственной промышленности: в 58 тт.

1903. Т. 9. Воронежская губерния. СПб. Тип. Т-ва «Народная польза», 156.

Trudy mestnyh komitetov o nuzhdah sel'skohozyajstvennoj promyshlennosti: v 58 tt. 1903. T. 9. Voronezhskaya guberniya. SPb. Tip. T-va «Narodnaya pol'za», 156.

43. Труды местных комитетов о нуждах сельскохозяйственной промышленности: в 58 тт. 1903. Т. 26. Симборская губерния. СПб. Тип. Т-ва «Народная польза», 540.

Trudy mestnyh komitetov o nuzhdah sel'skohozyajstvennoj promyshlennosti: v 58 tt. 1903. T. 26. Simbirskaya guberniya. SPb. Tip. T-va «Narodnaya pol'za», 540 .

44. Труды местных комитетов о нуждах сельскохозяйственной промышленности: в 58 тт. 1903. Т. 42. Тверская губерния. СПб. Тип. Т-ва «Народная польза», 475.

Trudy mestnyh komitetov o nuzhdah sel'skohozyajstvennoj promyshlennosti: v 58 tt. 1903. T. 42. Tverskaya guberniya. SPb. Tip. T-va «Narodnaya pol'za», 475 .

45. Чальцева Т.А. 2016. Становление и совершенствование системы сахарного акциза в Российской империи в середине XIX - начале XX вв. (на примере Курской губ.). Автореф. дис. канд. дис. Белгород, 25.

Chal'cevaT.A. 2016. Stanovlenie i sovershenstvovanie sistemy sahar-nogo akciza v Rossijskoj imperii v seredine XIX - nachale XX vv. (na primere Kurskoj gub.). Avtoref. dis. kand. dis. Belgorod, 25.

46. Шепелев Л.Е. 1963. Акционерные банки в годы Первой мировой войны. В кн.: Исторические записки. 73: 156-193.

Shepelev L.E. 1963. Akcionernye banki v gody Pervoj mirovoj vojny. V kn.: Istoricheskie zapiski. 73: 156-193. 